\title{
Повезивање библиотека и географских информационих система
}

\author{
Обрад Вучковац \\ Библиотека Дома културе „Студентски град”, Нови Београд \\ obrad.vuckovac@gmail.com
}

\begin{abstract}
Сажетак
Ефикасно коришћење информација о простору постало је једна од кључних компоненти у решавању глобалних проблема попут климатских промена, спречавања епидемија или сузбијања сиромаштва. Географски информациони системи (ГИС) омогућавају прикупљање, комбиновање и анализу просторних информација и од велике су користи при доношењу одлука, рационалног коришћења ресурса и спровођења превентивних мера тамо где су потребне. Они добијају све већи значај у академским и пословним круговима, а библиотеке могу на бројне начине да их уврсте у своје услуге. Обезбеђивање рачунара са инсталираним ГИС програмима, одржавање радионица, пружање помоћи при проналажењу просторних података, геореференцирање, развој дигиталних библиотека за похрањивање просторних података, само су неки од начина. У овом раду аутор ће представити пројекат развоја дигиталне библиотеке за прикупљање просторних података, који су започели библиотекари Дома културе „Студентски град” - Нови Београд у сарадњи са Географским факултетом Универзитета у Београду и Географским институтом „Јосиф Панчић” САНУ. Пројекат Дигитална библиотека просторних података може донети вишеструке користи студентима и професорима који користе ГИС, али и библиотекарима.
\end{abstract}

Кључне речи: географски информациони системи, ГИС, просторни подаци, инфраструктуре просторних података, дигитална библиотека просторних података, менаџмент информационих извора, стандарди за просторне податке, Дом културе „Студентски град”

\section{Подаци о простору}

Климатске промене, подизање нивоа мора, одрживо коришћење обрадивог земљишта, прекомерно крчење шума, контролисање болести, спречавање избијања епидемија, сузбијање глади и сиромаштва, неконтролисана урбанизација, само су неки од изазова са којима се среће све већи број заједница на нашој планети. Географске локације и информације о овим локацијама представљају једну од кључних компоненти у њиховом решавању. Информације о простору могу објаснити узроке због којих су се одређене појаве десиле у прошлости, и пружити увид када и где би могле да се понове у будућности. Ове информације могу помоћи при доношењу бољих одлука, рационалнијег коришћења ресурса и спровођења превентивних мера тамо где су потребне.

За ефикасно коришћење информација о простору од немерљиве су користи информациони системи који комбинују мапе, табеларне податке и способности њихове анализе. ${ }^{1}$ На тај начин организовани скупови „рачунарског хардвера, софтвера, особља и мрежа ради ефикасног прикупљања, складиштења, ажурирања, руковања, анализе, моделовања, преноса и приказа свих облика просторних информација" називају се іеоїрафски информациони сисиееми (ГНС). ${ }^{2}$

Они омогућавају корисницима да посматрају податке у просторном контексту и на тај начин добију одговоре на питања: где се нешто налази; који је правац простирања; да ли постоји неки

\footnotetext{
1 Rory Elliott, "Geographic information systems (GIS) and libraries: concepts, services and resources", Library Hi Tech News 31, 8 (2014): 8.

2 Verka Jovanović i dr., Geografski informacioni sistemi (Beograd: Univerzitet Singidunum, 2012$), 11$.
} 
образац у појављивању; колика је површина; да ли се у близини налазе други објекти од важности за испитивање; какав је однос између њих и сл. Такође, помоћу ГИС-а се могу правити симулације на основу којих се испитује одређена хипотеза, долази до нових сазнања и нових података.

Географски информациони системи налазе примену у многим областима. Најчешће се користе у пољопривреди, шумарству, екологији и заштити природне средине, саобраћају, архитектури и урбанизму, али све чешће проналазе своју примену и у другим наукама попут економије, медицине, лингвистике, друштвених наука и сл. Развојем бржег, широкопојасног и бежичног интернета, све јефтинијим и слободнијим приступом сателитским снимцима и системима глобалног позиционирања (GNSS) њ њихова примена постаје присутна у доношењу свакодневних одлука и олакшава радове попут избора најбоље руте за одлазак на море или препоруке за излазак са пријатељима.

За сваку успешну просторну анализу помоћу ГИС-а потребно је обезбедити „одговарајуће" податке. Подаци који се користе у њима могу се поделити на два главна типа: просторне и атрибутивне. Просторни подаци носе информацију о географској локацији, а то укључује географске координате (географску ширину и дужину, понекад и висину) и податке о пројекцији. Могу се поделити на векторске и растерске. Векторски приказују податке у виду тачака, линија или полигона, док растерски тип представља најчешће слику, у којој сваки пиксел (квадратић од којих је начињена слика) има одређену вредност на основу које се добија боја, висина или нека друга вредност. Сваки тип омогућава решавање различитих проблема приликом просторне анализе, а могуће је и њихово комбиновање. Атрибутивни подаци описују и класификују карактеристике просторних података. На пример, ако се све основне школе на територији неког града представе у векторском формату тачкама, подаци о називу школе, адреси, броју ученика и сл. сматраће се атрибутивним подацима. Они се најчешће налазе у табеларном облику.

И библиотеке све чешће својим корисницима нуде услуге ГИС-а. У овом раду биће представљен концепт по којем библиотекари могу да се укључе у овај растући светски тренд и како могу да искористе своје вештине и постану организатори просторних података (енгл. spatial data managers). Кад је реч о библиотекама у Србији, у раду ће бити представљена сарадња Географског факултета Универзитета у Београду, Географског института „Јосиф Панчић" САНУ и Библиотеке Дома културе „Студентски град” - Нови Београд на пројекту развоја дигиталне библиотеке просторних података.

\section{Географски информациони системи у библиотекама}

Убрзан развој софтвера и све већа доступност информација стављају пред библиотекаре све већи изазов да, осим досадашњег пружања помоћи у „навигацији" кроз свет информација, уче кориснике и како да уйошребљавају информације. Пружањем ГИС услуга библиотеке проширују могућности употребе информација не ограничавајући се само на просто посматрање података у просторном контексту (на мапама или у тродимензионалном приказу), већ кроз могућност манипулисања упитима и анализама током којих настају нове информације. ${ }^{4}$

Библиотеке на разне начине успевају да примене ГИС као услугу за кориснике: обезбеђивањем рачунара са инсталираним ГИС програмима; одржавањем радионица на којима кориснике упознају са основама њиховог коришћења; пружањем помоћи при проналажењу специфичних база података; конвертовањем формата података; геореференцирањем; израдом приручника за употребу софтвера и база података и сл. ${ }^{5}$ Пошто је потребно уложити додатан напор да би се стекле макар основне вештине за рад у ГИС програмима, решење за кориснике

\footnotetext{
${ }_{3}^{3}$ GNSS -енгл., Global Navigation Satellite System. Сигурно најпознатији продукт овог система је GPS (Global Positioning System).

${ }^{4}$ Rory Elliott, "Geographic information systems (GIS) and libraries: concepts, services and resources": 9.

${ }^{5}$ Rhonda Houser, "Building a Library GIS Service from the Ground Up", Library Trends 55, 2 (2006): 318-320.
} 
који немају довољно програмерског искуства је софтвер под називом "ГИС Лајт". ${ }^{6}$ Помоћу њега је знатно олакшано коришћење ГИС-а, што омогућава академским и другим научним библиотекама да постану главни ресурси за пружање помоћи и осталих услуга при приказивању података и изради мапа. ${ }^{7}$ Ове алатке обезбеђују визуелизацију, манипулисање и дељење података на брз и једноставан начин, али нису погодне за извођење комплексних израчунавања и просторних анализа. ${ }^{8}$ За овакве врсте послова потребно је овладати вештинама „традиционалних" ГИС програма. ${ }^{9}$ Ипак, због лакоће коришћења, „ГИС Лајт” представља одлично решење које библиотекари могу да искористе за обуку својих корисника, а и да се сами на једноставан и брз начин упознају са материјом.

Библиотеке се, такође, све чешће одлучују за услуге обезбеђивања приступа просторним подацима креирањем посебних портала и дигиталних библиотека. ${ }^{10}$ На овај начин својим корисницима могу знатно олакшати претраживање и проналажење података. Постоји више извора који пружају скупове просторних података, а то су: државне институције, научне установе, непрофитне организације, универзитетски репозиторијуми и подаци које су генерисали сами корисници. Библиотекари могу организовано да приступе овим скуповима података, обједине их у оквиру једне локације као што је дигитална библиотека и тиме их учине доступним за своје кориснике.

Америчке и канадске универзитетске библиотеке отишле су најдаље у имплементирању ове услуге. Универзитети Корнел, Ајдахо и Орегон су развој својих дигиталних колекција прилагодили подацима који се тичу савезне државе у којој се налазе; неколико америчких универзитета (Тафтс, Харвард, МИТ, Принстон, Станфорд и Универзитет Калифорније у Берклију) оформило је конзорцијум за заједнички развој колекција просторних података, а на сличан подухват се одлучило преко двадесет универзитетских библиотека из канадског Онтарија (Савет универзитетских библиотека Онтарија). ${ }^{11}$ Што се тиче европских библиотека, на Универзитету у Единбургу су развијене две дигиталне колекције: GoGeo (за приступ метаподацима владиних и академских институција) и ShareGeo (дигитална колекција коју истраживачи британских високошколских и научних установа користе за похрањивање и дељење својих просторних података). ${ }^{12}$

Изградња и одржавање дигиталних библиотека за просторне податке представља одличну прилику за библиотекаре да искористе своје вештине прикупљања, описивања и организовања података. Осим ових „традиционалних" библиотекарских послова ту су и друге могућности и изазови попут организовања одговарајуће структуре за организацију података, усаглашавање инфраструктуре, процеса рада и терминологије, израда контролисаних речника итд. ${ }^{13}$

\section{Дигитална библиотека просторних података}

По угледу на већ наведене библиотеке америчких универзитета, Библиотека Дома културе „Студентски град" (ДКСГ) дошла је на идеју да, у сарадњи са Географским факултетом Универзитета у Београду и Географским институтом „Јован Цвијић” САНУ, изгради заједничку

\footnotetext{
${ }^{6}$ GIS Lite.

7 Kathleen W. Weessies and Daniel S. Dotson, "Mapping for the Masses: GIS Lite and Online Mapping Tools in Academic Libraries", Information Technology \& Libraries 32, 1 (2013): 23.

${ }^{8}$ Mark Zastrow, "Science on the Map", Nature 519, 7541 (2015): 120.

9 Неки од најпознатијих ГИС програма су: ArcGIS (производ највеће компаније за развој ГИС софтвера - ESRI), TerrSet (раније IDRISI), и бесплатни програми GRASS GIS и QGIS.

${ }^{10}$ Jessica Clemons, "Identifying Local Hidden Data Sets: The First Step to Begin a Geospatial Data Collection", Journal of Map \& Geography Libraries 11, 1 (2015): 5-17; Tsering Wangyal Shawa, "Building a System to Disseminate Digital Map and Geospatial Data Online", Library Trends 55, 2 (2006): 254-263.

${ }^{11}$ Christine Kollen et al., "Geospatial Data Catalogs: Approaches by Academic Libraries", Journal of Map \& Geography Libraries 9, 3 (2013): 282-284.

${ }^{12}$ Ibid., 283.

${ }^{13}$ Nicole Ningning Kong, "Exploring Best Management Practices for Geospatial Data in Academic Libraries", Journal of Map \& Geography Libraries 11, 2 (2015): 209-210.
} 
дигиталну библиотеку у коју би се похрањивали просторни подаци, мапе и друге информације настале ГИС анализом.

Основу за стварање библиотеке овог типа представљали би подаци до којих су дошли студенти основних и мастер студија, докторанди и други научни радници приликом свог рада на ГИС пројектима. Наравно, и други просторни подаци, попут граница општина, држава, правци путева и река, локације школа, болница и сл. чиниће важан део базе података. Оваква дигитална библиотека просторних података послужила би као почетна тачка и главни ресурс свакоме ко буде желео да изведе неку ГИС анализу.

За извођење оваквог пројекта биће потребно одредити политику селекције и набавке просторних података, припремити инфраструктурне (пред)услове попут сервера за смештај података и обезбедити сараднике и друго особље који ће радити на одржавању веб-сајта, уношењу метаподатака и контроли њиховог квалитета. Овакав вид сарадње довешће до боље организације и доступности просторних података који су објављени или се генеришу на факултетима и институтима Универзитета у Београду, а библиотекари ће стицати нова искуства у одржавању библиотека података (енгл. data libraries). Осим Географског, у оваквом пројекту могли би да учествују Саобраћајни, Шумарски, Пољопривредни, Архитектонски, Грађевински факултет и друге научне установе Универзитета у Београду.

Научне установе које не припадају Универзитету у Београду могу да приложе метаподатке својих просторних података који се налазе похрањени на њиховим серверима. Ове институције задржавају свако право да своје податке не објављују у слободном приступу и за њихов приступ и преузимање могу тражити новчану накнаду. У овом случају Дигитална библиотека послужиће само као „промотер” ових извора података и трудиће се да усклади метаподатке тако да одговарају свим стандардима који се захтевају.

Постоји могућност да се помоћу протокола ОАІ-PMН затражи приступ метаподацима других установа које имају своје репозиторијуме и дигиталне колекције. У оваквим случајевима Дигитална библиотека просторних података биће само „посредник” при објављивању ових података, односно пружаће услуге приказа метаподатака, а за преузимање корисник ће лично морати да се обрати овим институцијама или да затражи помоћ библиотекара при договору око преузимања.

Главна замисао пројекта је да се подаци о простору које прикупљају београдски факултети нађу у слободном приступу. Универзитет у Београду се, потписивањем Берлинске декларације о отвореном приступу научном знању, ${ }^{14}$ прикључио растућем делу научне заједнице која се залаже за јавну доступност садржаја који научна заједница ствара и објављује. Концепт отворености података предвиђа да одређене податке (пре свега, оне које генеришу државне агенције или научне установе финансиране из државног буџета) треба учинити доступним свакоме, уз могућност поновног објављивања у било ком облику и без ограничавања ауторским или другим правима. Лакше укључивање грађана у јавни ангажман, подстицање развоја ИТ сектора, идентификовање потреба заједнице, само су неке од предности отворености података. ${ }^{15}$

\section{Развој}

Пре изградње Дигиталне библиотеке просторних података неопходно је упознати се са одговарајућом терминологијом и стандардима из области геоинформација. На првом месту треба споменути стандарде за чији развој је одговоран Технички комитет за развој стандарда из области геоинформација - ISO/TC 211. То су стандарди из серије 19100, од којих су за овај

\footnotetext{
${ }^{14}$ Max Planck Society, Berlin Declaration on Open Access to Knowledge in the Sciences and Humanities, https://openaccess.mpg.de/BerlinDeclaration (preuzeto 5. 4. 2017).

${ }^{15}$ Maxat Kassen, "A promising phenomenon of open data: A case study of the Chicago open data project", Government Information Quarterly 30, 4 (2013): 512.
} 
пројекат најважнији ISO 19110 - стандард за методологију каталогизације облика, ISO 19115 - стандард за метаподатке и ISO 19139 - стандард за XML-шему метаподатака. ${ }^{16}$

Осим наведених, битно је савладати и основне стандарде које је израдио Отворени геопросторни конзорцијум (OGC) ${ }^{17}$ - међународна организација која окупља преко 500 комерцијалних, владиних, непрофитних и научних организација. OGC стандарди су отвореног типа и развијају се за формате просторних података, сервисе, анализе и дељење података. Стандардни формати за приказивање просторних података су Shapefile, који је развила компанија ESRI, највећа софтверска компанија на свету која се бави развојем ГИС-а, и KML ${ }^{18}$ - специјално прилагођени формат за приказивање просторних података у програму Гугл Земља (енгл. Google Earth). Посебна пажња посвећена је упознавању са OGC стандардима за ГИС сервисе - WMS (Web Map Service) за приказивање мапа и других растерских података у ГИС окружењу и WFS (Web Feature Service) за преузимање и коришћење векторских и атрибутивних података. Meђународна организација за стандардизацију ISO усвојила је многе OGC стандарде.

Америчка струковна удружења су и у погледу израде ГИС-а, као и у многим другим примерима развоја дигиталне технологије, пионири у изради стандарда. Организација Федерални комитет за географске податке (FGDC) ${ }^{19}$ је, почетком деведесетих година 20. века, почела са развојем првог стандарда за метаподатке просторних података. FGDC стандарди чинили су основу за међународно усаглашавање у серији 19100 ISO стандарда. Међународни стандард за метаподатке ISO 19115 објављен је 2003. године, а ревизију је добио десет година касније.

Поред стандарда за приказивање и опис просторних података, потребно је упознати се и са европском директивом INSPIRE, ${ }^{20}$ чија је намена усаглашавање описа просторних података међу земљама чланицама и земљама кандидатима за улазак у Европску унију. Ова директива предлаже основе за грађење инфраструктуре просторних података (енгл. Spatial Data Infrastructure - SDI) за потребе заштите природне околине. INSPIRE директива је посебно важна зато што је Национала инфраструктура геопросторних података Србије (НиГП) изграђена следећи ова упутства. Било би пожељно да Дигитална библиотека просторних података следи ова упутства и буде компатибилна са главним републичким репозиторијумом просторних података. У будућим фазама развоја могло би да дође до размене просторних података и усаглашавања правила за њихов пренос.

За прикупљање и описивање просторних података одабран је програм Геонетворк (енгл. Geonetwork opensource). Развила га је Организација за храну и пољопривреду Уједињених нациja $(\mathrm{FAO})^{21}$ са циљем да повеже просторне податке са одговарајућим метаподацима поштујући све међународне стандарде. Показао се као добро решење, пре свега због цене (бесплатан) и због отвореног ко̂да (open source). Ова последња карактеристика дозвољава преузимање оригиналног коิда, његово мењање и прилагођавање потребама корисника програма. Дакле, уз поседовање адекватних програмерских вештина, могуће је извести промене на програму, као што су мењање изгледа, побољшање претраживача, уградња тезауруса и сл.

Геонетворк нуди прегледан и прилагодљив интерфејс за унос метаподатака. Поља за унос прилагођена су директиви INSPIRE, а за проверу компатибилности уграђен је софтвер за контролу, тзв. валидатор. Податке је могуће класификовати користећи неке од већ уграђених тезауруса, као што је GEMET, ${ }^{22}$ увозом или креирањем сопственог контролисаног речника. За претраживање просторних података уграђен је Lucene, претраживач заснован на програмском језику Јава.

\footnotetext{
${ }^{16}$ Verka Jovanović i dr., Geografski informacioni sistemi, 97-102.

${ }^{17}$ OGC - Open Geospatial Consortium

${ }^{18}$ Keyhole Markup Language

${ }^{19}$ FGDC - Federal Geographic Data Committee

${ }^{20}$ INSPIRE - Infrastructure for Spatial Information in the European Community

${ }^{21} \mathrm{FAO}$ - Food and Agriculture Organization (Организација за храну и пољопривреду Уједињених нација)

${ }^{22}$ GEMET - General Multilingual Environmental Thesaurus
} 
У пакету са овим програмом долази и Геосервер - софтвер помоћу којег је омогућено похрањивање података на сервер и усаглашавање са OGC стандардима и сервисима, пре свега ca WMS и WFS. Помоћу њих кориснику је олакшано директно прегледање просторних података на самом порталу Дигиталне библиотеке.

Поред PDF и XML формата, све метаподатке могуће је преузети и преко RDF/XML стандарда за опис метаподатака који због свог субјекат-предикат-објекат модела представља главну компоненту Семантичког веба. Ова особина пружа велику предност и отвара многе могућности када је у питању развој дигиталне библиотеке у будућности.

\section{Особље}

Истраживања су показала да број запослених на оваквим пројектима варира у зависности од комплексности рада и финансијских могућности библиотеке или њене матичне установе. ${ }^{23} \mathrm{Ha}$ пример, библиотека Универзитета Колумбија ангажовала је једног библиотекара са пуним радним временом за одржавање њеног репозиторијума просторних података, библиотека Универзитета у Единбургу на сличном пројекту ангажовала је петоро запослених, док је Савет универзитетских библиотека Онтарија током развојне фазе запослио осам радника (пројектног менаџера, специјалисту за систем, ГИС аналитичара, библиотекара за метаподатке и четири програмера). ${ }^{24}$

За овај пројекат било би потребно укључити најмање четворо запослених. Осим једног библиотекара који би радио на организовању и креирању метаподатака, неопходно је ангажовати једног систем-администратора, пошто је неопходан неометан рад мреже и уклањање било каквих сметњи у раду. За успешно подешавање и побољшавање рада програма Геонетворк неопходно је ангажовати једног програмера са добрим познавањем програмског језика Јава. Ово радно место било би свакако добродошло, макар у почетној фази пројекта. Такође, препоручује се и ангажовање једног студента-помоћника (пожељно би било и више од једног) са добрим познавањем географских информационих система, пре свега као испомоћ приликом попуњавања метаподатака и похрањивања нових јединица.

Свакако је потребно једно радно тело које би одлучивало о квалитету просторних података и њиховом укључивању у дигиталну библиотеку. Чиниле би га особе које су упознате са ГИС технологијама и које имају јасну представу о политици прикупљања просторних података и њиховог пружања на коришћење.

\section{Закључак}

Бројни су изазови пред развојем овог пројекта. Ипак, искуства америчких библиотека показују да уређена колекција просторних податка може бити од велике користи студентима и професорима који користе географске информационе системе. ${ }^{25}$ Иако је ова идеја тек у зачетку, њена пуна имплементација очекује се до краја 2017. године. На овај начин Библиотека Дома културе "Студентски град" моћи ће да пружи драгоцено искуство за сваки даљи развој и примену географских информационих система у библиотекама.

Знање стечено на оваквим пројектима омогућиће библиотекарима боље позиционирање када су у питању послови пружања ГИС услуга. Прецизније речено, библиотекарима се пружа прилика да активно учествују у ГИС пројектима и да истражују најбоља решења за управљање подацима током било ког дела развоја пројекта. ${ }^{26}$

\footnotetext{
${ }^{23}$ Christine Kollen et al., "Geospatial Data Catalogs: Approaches by Academic Libraries": 287.

${ }^{24}$ Ibid.

${ }^{25}$ Ibid.: 276-295.

${ }^{26}$ Nicole Ningning Kong, "Exploring Best Management Practices for Geospatial Data in Academic Libraries": 220.
} 
Вучковац О. „Повезивање библиотека и географских информационих система", 34-40

\section{Литература и извори:}

1. Clemons, Jessica. "Identifying Local Hidden Data Sets: The First Step to Begin a Geospatial Data Collection". Journal of Map \& Geography Libraries 11, 1 (2015): 5-17.

2. Elliott, Rory. "Geographic information systems (GIS) and libraries: concepts, services and resources". Library Hi Tech News 31, 8 (2014): 8-11.

3. Houser, Rhonda. "Building a Library GIS Service from the Ground Up". Library Trends 55, 2 (2006): 315-326.

4. Jovanović, Verka, Branislav Đurđev, Zoran Srđić i Uglješa Stankov. Geografski informacioni sistemi. Beograd: Univerzitet Singidunum, 2012.

5. Kassen, Maxat. "A promising phenomenon of open data: a case study of the Chicago open data project". Government Information Quarterly 30, 4 (2013): 508-513.

6. Kollen, Christine, Cynthia Dietz, Joy Suh, and Angela Lee. "Geospatial Data Catalogs: Approaches by Academic Libraries". Journal of Map \& Geography Libraries 9, 3 (2013): 276-295.

7. Kong, Nicole Ningning. "Exploring Best Management Practices for Geospatial Data in Academic Libraries". Journal of Map \& Geography Libraries 11, 2 (2015): 207-225.

8. Max Planck Society. Berlin Declaration on Open Access to Knowledge in the Sciences and Humanities. https:// openaccess.mpg.de/Berlin-Declaration (preuzeto 5. 4. 2017)

9. Shawa, Tsering Wangyal. "Building a System to Disseminate Digital Map and Geospatial Data Online". Library Trends 55, 2 (2006): 254-263.

10. Weessies, Kathleen W. and Daniel S. Dotson. "Mapping for the Masses: GIS Lite and Online Mapping Tools in Academic Libraries". Information Technology \& Libraries 32, 1 (2013): 23-35.

11. Zastrow, Mark. "Science on the Map". Nature 519, 7541 (2015): 119-120.

\section{Connecting Libraries with Geographic Information Systems}

\section{Summary}

There are numerous challenges facing modern communities in the world of today. Climate change, poverty, epidemics, land usage, are just some of them. Effective use of information about the exact locations has become one of the key components in addressing these global issues. Geographic information systems (GIS) enable collecting, visualization, handling and analyzing spatial information. They are very useful in decision making, rational usage of resources and taking precautions where needed. Geographic information systems are gaining increasing importance in academic and business environment. With the growth of the amount of data collected from satellites, mobile phones, cars, house appliances and other sensors, the demand for information specialists with skills in gathering, describing, organizing and searching data is also growing. Libraries can incorporate GIS into their services in different ways: providing computers with installed GIS software, designing and conducting workshops, assistance in spatial data gathering, georeferencing, etc. The development of specialized portals and digital libraries for storing spatial data are also good examples of implementation and use of GIS services in libraries. University libraries of the USA and Canada have made the greatest progress in implementing this practice. It is well received by the users, because it significantly reduces time and effort needed for gathering the right spatial data. The librarians of the Cultural Center Studentski Grad are working on the development of a digital library for gathering spatial data, in cooperation with the Geographic Faculty and the Geographic Institute Josif Pančić. The project will be executed using Geonetwork opensource, the free and open-source platform for developing spatial data infrastructure. There are many challenges facing the development of the project: designing workflows, data gathering policies, quality control assessment, staffing, implementing guidelines and standards, etc. The project Digital Spatial Data Library can bring multiple benefits to students and professors who use GIS in their work, and as for librarians, it can enrich them with knowledge and experience when it comes to providing new services for library users.

Keywords: geographic information systems, GIS, spatial data, spatial data infrastructures, digital spatial data library, information resource management, spatial data standards, Cultural Center Studentski Grad 